\title{
The Arctic vortex in March 2011: a dynamical perspective
}

\author{
M. M. Hurwitz ${ }^{1,2}$, P. A. Newman ${ }^{2}$, and C. I. Garfinkel ${ }^{3}$ \\ ${ }^{1}$ Goddard Earth Sciences Technology and Research (GESTAR), Morgan State University, Baltimore, MD, USA \\ ${ }^{2}$ NASA Goddard Space Flight Center, Greenbelt, MD, USA \\ ${ }^{3}$ Johns Hopkins University, Baltimore, MD, USA
}

Received: 5 July 2011 - Published in Atmos. Chem. Phys. Discuss.: 5 August 2011

Revised: 31 October 2011 - Accepted: 3 November 2011 - Published: 17 November 2011

\begin{abstract}
Despite the record ozone loss observed in March 2011, dynamical conditions in the Arctic stratosphere were unusual but not unprecedented. Weak planetary wave driving in February preceded cold anomalies in the polar lower stratosphere in March and a relatively late breakup of the Arctic vortex in April. La Niña conditions and the westerly phase of the quasi-biennial oscillation (QBO) were observed in March 2011. Though these conditions are generally associated with a stronger vortex in mid-winter, the respective cold anomalies do not persist through March. Therefore, the La Niña and QBO-westerly conditions cannot explain the observed cold anomalies in March 2011. In contrast, positive sea surface temperature anomalies in the North Pacific may have contributed to the unusually weak tropospheric wave driving and strong Arctic vortex in late winter 2011.
\end{abstract}

\section{Introduction}

In the Arctic stratosphere, chemical ozone loss takes place each year in the late winter (WMO, 2011). Arctic ozone loss represents the interaction between chemistry and climate: heterogeneous ozone depletion on polar stratospheric clouds (PSCs) requires the presence of halogens, sunlight and temperatures below approximately $195 \mathrm{~K}$. Rex et al. (2004 and 2006) calculated that the severity of large ozone loss events has been increasing over the last few decades, and speculated that increased radiative cooling by greenhouse gases plays a role.

Severe ozone loss was observed in the Arctic stratosphere in 2011. On 14 March, the Alfred Wegener Institute in Germany reported that "unusually low temperatures in the Arctic ozone layer have recently initiated massive ozone de-

\section{Correspondence to: M. M. Hurwitz} (margaret.m.hurwitz@nasa.gov) pletion" (http://www.awi.de/en/news/press_releases). Manney et al. (2011) have since determined that the spring 2011 ozone loss was "unprecedented": During the 2010-2011 winter, the Arctic vortex was the most isolated and the timeintegrated PSC volume was the largest ever observed. These conditions enabled severe ozone loss in late winter. Vortex averaged lower stratospheric ozone was unusually low beginning in late February, and by March, reached values comparable to those recently observed in the Antarctic stratosphere in September. Figure 1a shows that March total ozone in the $60-80^{\circ} \mathrm{N}$ region was the lowest of the satellite era (total ozone dataset updated from Stolarski and Frith, 2006).

Circulation patterns in the North Pacific sector have been linked to anomalous Arctic lower stratospheric conditions in winter. Orsolini et al. (2009) found that the largest observed Arctic PSC volumes were on average preceded by a weakening of the climatological, tropospheric low in the subpolar Far East and North Pacific regions. This type of "blocking" event in the North Pacific, also known as the positive phase of the Western Pacific teleconnection pattern (WP; Wallace and Gutzler, 1981), effectively weakens the upward propagation of upper tropospheric planetary waves (see e.g., Woollings et al., 2010).

In addition, two tropical phenomena contribute to interannual variability in the Arctic stratosphere in winter: El Niño/Southern Oscillation (ENSO) and the quasibiennial oscillation (QBO). Holton and Tan (1980) and Lu et al. (2008) showed that the phase of the QBO modulates the region in which planetary waves can propagate in the stratosphere, thus affecting the strength of the Arctic vortex in mid-winter. The vortex tends to be stronger during the westerly phase of the QBO than during the easterly phase. Similarly, planetary wave driving is relatively stronger during El Niño (ENSO warm phase) events than during La Niña (ENSO cold phase) events (e.g., Garfinkel and Hartmann, 2008).

Published by Copernicus Publications on behalf of the European Geosciences Union. 


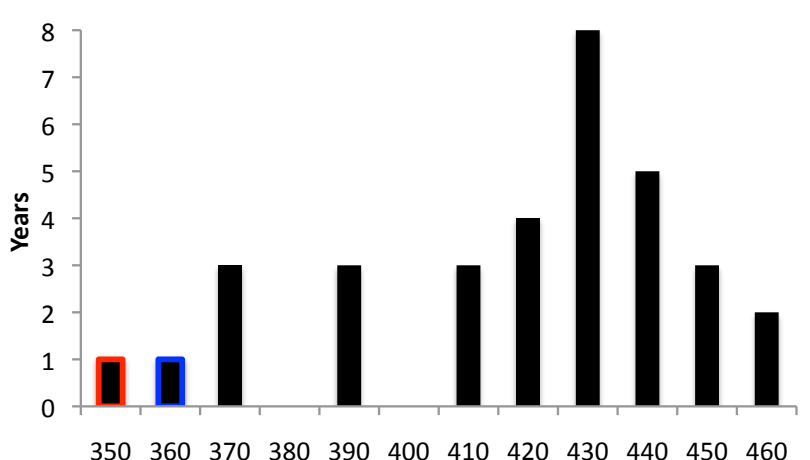

(a) March Total Ozone, $60-80 \mathrm{~N}$ TOMS/SBUV [DU]

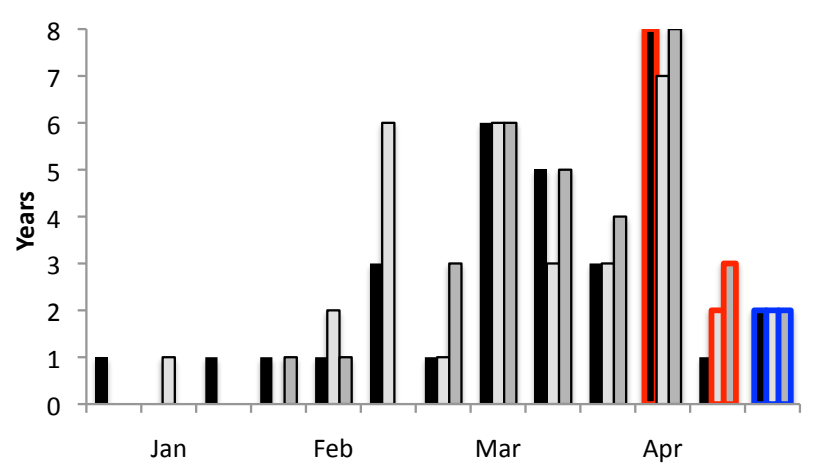

(c) Arctic Vortex Breakup Date at $450 \mathrm{~K}$

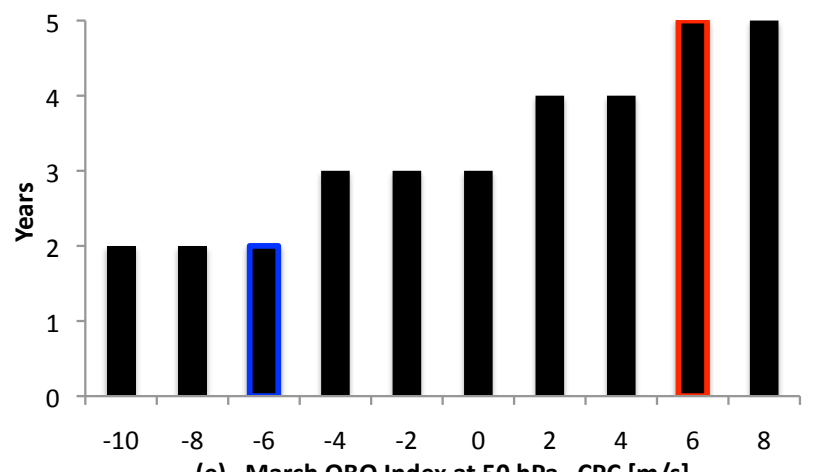

(e) March QBO Index at $50 \mathrm{hPa} \mathrm{CPC}[\mathrm{m} / \mathrm{s}]$

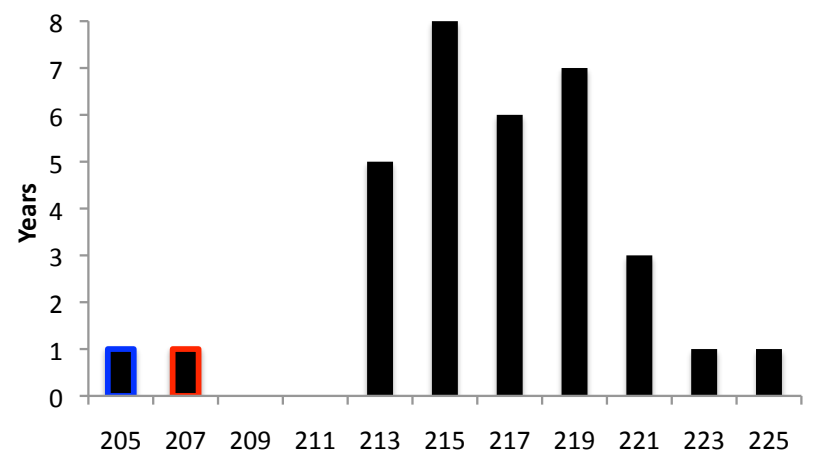

(b) March Polar Cap Temperature at 50hPa MERRA [K]

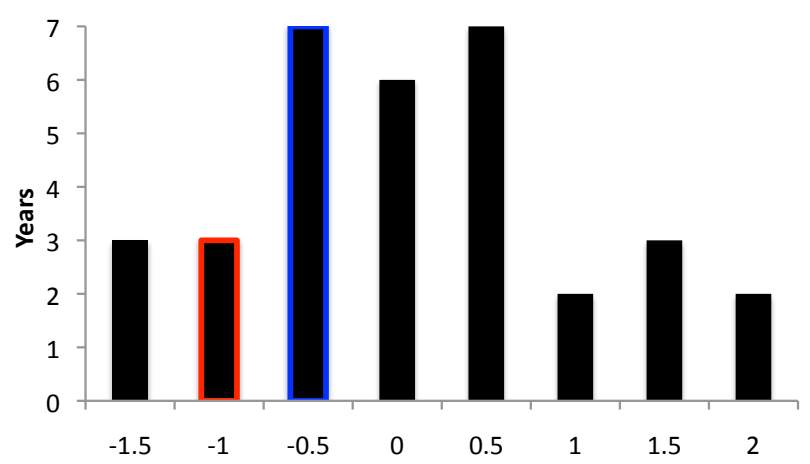

(d) JFM Nino 3.4 Anomaly [K]

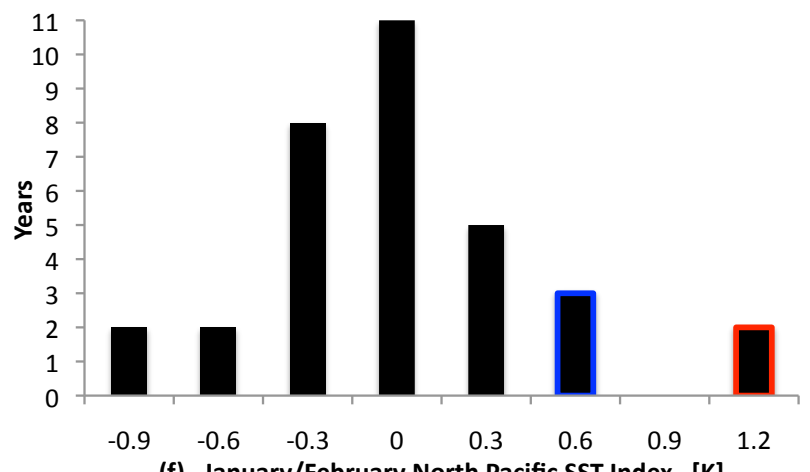

(f) January/February North Pacific SST Index [K]

Fig. 1. Histograms of total ozone and dynamical conditions during the 1979-2011 period: (a) March total ozone averaged between 60$80^{\circ} \mathrm{N}$ [DU]; (b) March Arctic polar cap temperature at $50 \mathrm{hPa}$ [K]; (c) Date of the Arctic vortex breakup at $450 \mathrm{~K}$ based on the NCEP-2 (black), NCEP-1 (light gray) and CPC (dark gray) reanalyses, binned into 10-day intervals; (d) January-February-March SST anomaly in the Niño 3.4 region $[\mathrm{K}]$; (e) March zonal winds in the equatorial region at $50 \mathrm{hPa}\left[\mathrm{m} \mathrm{s}^{-1}\right.$ ]; (f) January/February SST anomaly in the $40-50^{\circ} \mathrm{N}$, $160-200^{\circ} \mathrm{E}$ region $[\mathrm{K}]$. Red (blue) outlines indicate the location of 2011 (1997) conditions. X-axis values indicate the mid-point of each histogram bin.

While the Arctic vortex was relatively strong throughout the winter, Manney et al. (2011) showed that the exceptional nature of 2010-2011 was not apparent until late February and March. Thus, the goals of this paper are to: (1) document the dynamical conditions that made possible the record ozone loss in March 2011; and (2) attribute these conditions to known sources of dynamical variability. Section 2 will describe the datasets and diagnostics used to perform this anal- ysis. In Sect. 3, March 2011 will be examined in the context of the satellite era. The qualitative relationship of the March 2011 conditions in the Arctic stratosphere to ENSO and the phase of the QBO will be considered. In addition, the possible role of North Pacific sea surface temperature variability in the anomalous dynamical conditions in the Arctic vortex in March 2011 will be examined. The results are further discussed in Sect. 4. Section 5 provides a brief summary. 

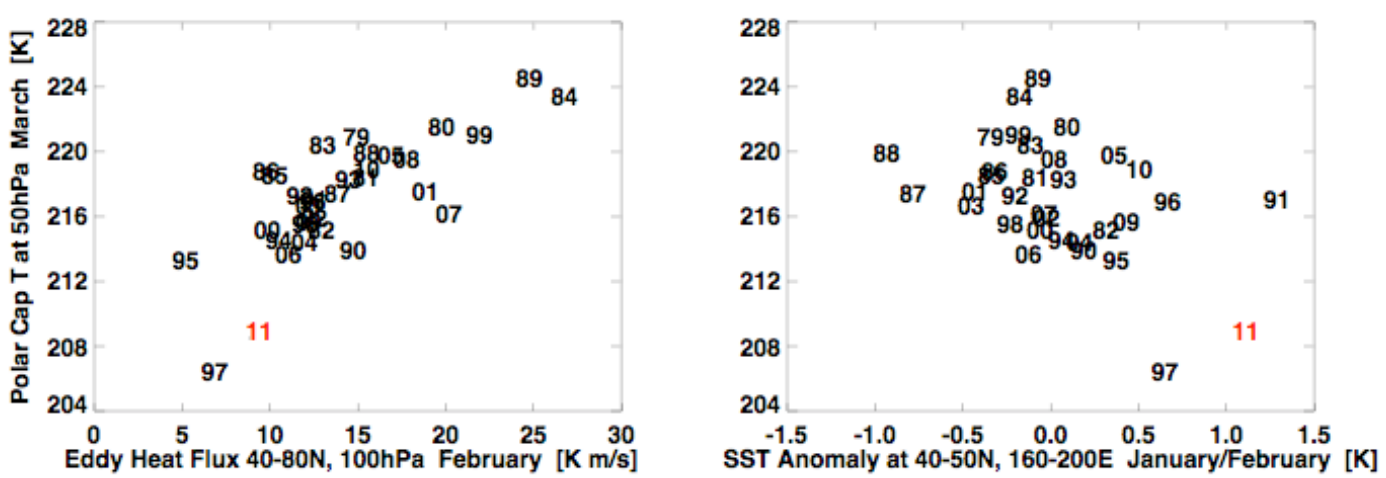

Fig. 2. (left) Meridional eddy heat flux at $40-80^{\circ} \mathrm{N}, 100 \mathrm{hPa}\left[\mathrm{K} \mathrm{m} \mathrm{s}^{-1}\right]$ in February as a function of Arctic polar cap temperature at $50 \mathrm{hPa}$ $[\mathrm{K}]$ in March; (right) January/February SST anomaly at $40-50^{\circ} \mathrm{N}, 160-200^{\circ} \mathrm{E}[\mathrm{K}]$ as a function of Arctic polar cap temperature at $50 \mathrm{hPa}$ $[\mathrm{K}]$ in March. Eddy heat flux, SST anomaly and temperature values are denoted by year number (e.g., "11" denotes 2011).

\section{Data and diagnostics}

Sea surface temperature (SST) and atmospheric diagnostics are used to understand conditions in the Arctic stratosphere in March 2011. The present analysis spans the satellite era (1979-2011) and focuses on the Northern Hemisphere midto late winter (January through March). Zonal winds, temperature and eddy heat flux fields are derived from the Modern Era Retrospective-Analysis for Research and Applications (MERRA) reanalysis. The MERRA reanalysis is based on an extensive set of satellite observations and on the Goddard Earth Observing System Data Analysis System, Version 5 (GEOS-5) (Bosilovich et al., 2008; Rienecker et al., 2011). The MERRA reanalysis has vertical coverage up to $0.1 \mathrm{hPa}$, and for this study, is interpolated to $1.25^{\circ} \times 1.25^{\circ}$ horizontal resolution.

The phase of the QBO is characterized by zonal winds in the equatorial region at $50 \mathrm{hPa}$. Monthly mean values of the 50-hPa QBO index (http://www.cpc.ncep.noaa.gov/data/ indices/qbo.u50.index) are used in this study.

The springtime breakup of the Arctic vortex is calculated for each year. On the $450 \mathrm{~K}$ isentropic surface (i.e., in the lower stratosphere), the breakup date is defined as the date when the five-day running mean of zonal winds at the vortex edge falls below approximately $15.2 \mathrm{~m} \mathrm{~s}^{-1}$, following the criteria of Nash et al. (1996). The present analysis considers breakup dates based on the NCEP-1 (Kalnay et al., 1996), NCEP-2 (Kanamitsu et al., 2002) and NOAA Climate Prediction Center (CPC) (Gelman et al., 1986; Nagatani et al., 1988; Finger et al., 1993) meteorological reanalyses.

Monthly mean SST fields are taken from the Hadley Centre Global Sea Ice and Sea Surface Temperature (HadISST1) dataset (Rayner et al., 2003). Sea surface temperature anomalies in the eastern equatorial Pacific are characterized by the Niño 3.4 index (see http://www.cpc.noaa.gov/data/ indices). Trenberth (1997) defines a conventional El Niño event as a sustained period (usually six months or more) when the Niño 3.4 index exceeds 0.4 , while a La Niña event is defined as a sustained period when the Niño 3.4 index is less than -0.4 .

\section{Results}

\subsection{March 2011 in a historical context}

In 2011, the Arctic vortex was colder, stronger and more persistent than usual. Figure 1 shows histograms of Arctic total ozone, polar cap temperature, breakup date of the Arctic vortex, ENSO index, QBO index and North Pacific SST index in 2011 with respect to the 1979-2011 period. A histogram of March mean temperatures for the Arctic polar cap at $50 \mathrm{hPa}$ is shown in Fig. 1b. The March 2011 temperature of $207.3 \mathrm{~K}$ (indicated by the red outline) is more than two standard deviations lower than the climatological mean value $(216.4 \mathrm{~K})$ and is the second-lowest value in the 1979 2011 period. The lowest value $(204.9 \mathrm{~K}$, indicated by the blue outline) occurred in 1997.

The breakup of the Arctic vortex occurs in spring. A histogram of breakup dates at $450 \mathrm{~K}$ is shown in Fig. 1c. The breakup date in 2011 was 19 April in the NCEP-2 reanalysis, later than the mean date of 20 March in the NCEP reanalyses and 10 April in the CPC reanalysis. The breakup date in 2011 was, depending on the zonal wind dataset, either the third or fourth latest of the satellite era. The late breakup of the Arctic vortex is consistent with the low temperatures and total ozone observed in March 2011 (see Fig. 1a and b).

Unusually cold conditions in the Arctic stratosphere in March 2011 correspond with unusually weak planetary wave driving in February 2011. Newman et al. (2001) found that polar lower stratospheric temperature is correlated with midlatitude eddy heat flux at $100 \mathrm{hPa}$, with a 1-2 month lag; this finding suggests that weaker than usual eddy heat flux in February should correspond with a colder than usual Arctic lower stratosphere in March. Figure 2 (left) shows that 
February eddy heat flux and March polar cap temperature at $50 \mathrm{hPa}$ are indeed well correlated (with a correlation coefficient of 0.75), and highlights the unusually low values observed in 2011.

March temperature anomalies in 2011 and 1997 are shown in Fig. 3a and b. In both 1997 and 2011, the Arctic stratosphere cooled strongly while the mid-latitudes and Arctic troposphere warmed weakly. Consistent with these temperature differences, zonal winds were relatively stronger at high latitudes; peak wind differences exceeded $20 \mathrm{~m} \mathrm{~s}^{-1}$ at $10 \mathrm{hPa}$ at high latitudes (not shown). The magnitude of the stratospheric cooling was larger in 1997 (e.g., the polar cap temperature at $50 \mathrm{hPa}$ was $11.5 \mathrm{~K}$ lower than the climatological mean) than in 2011 (9.1 K lower). Similarly, February eddy heat flux was weaker in $1997\left(7.0 \mathrm{~K} \mathrm{~m} \mathrm{~s}^{-1}\right.$ less than the climatological mean of $14.8 \mathrm{~K} \mathrm{~m} \mathrm{~s}^{-1}$ at $40-80^{\circ} \mathrm{N}, 100 \mathrm{hPa}$; see Fig. 2, left) than in $2011\left(5.5 \mathrm{~K} \mathrm{~m} \mathrm{~s}^{-1}\right.$ less $)$.

\subsection{Influence of ENSO and the QBO on the Arctic stratosphere in March}

La Niña and QBO-westerly conditions persisted through March 2011. The Niño 3.4 index was strongly negative in January through March 2011, indicating La Niña conditions (Fig. 1d). In March 2011, equatorial zonal winds at $50 \mathrm{hPa}$ were approximately $6 \mathrm{~m} \mathrm{~s}^{-1}$ (Fig. 1e), indicating the westerly phase of the QBO.

This section compares the temperature anomalies observed in March 2011 with those observed during typical La Niña conditions and during the westerly phase of the QBO. The March temperature response to La Niña events is estimated by comparing years when the Niño 3.4 index is equal to or less than -1 (as in 2011) with an ENSO neutral composite (i.e., winters when the Niño 3.4 index is between -0.4 and 0.4). Figure $3 \mathrm{c}$ shows that, in the Arctic stratosphere, the typical March temperature response to a La Niña event is a weak warming. Thus, the La Niña response is inconsistent with the observed strong polar cooling in both 1997 and 2011.

The QBO was in its westerly phase during the 2010-2011 winter season (Fig. 1e). The March temperature response to the phase of the QBO is estimated by comparing composites of QBO-westerly years and QBO-easterly years. The typical March temperature response is a relative warming of the Arctic stratosphere that increases with altitude (Fig. 3d). As for the La Niña response, the temperature response to QBOwesterly conditions is inconsistent with the observed strong polar cooling in both 1997 and 2011.

In summary, the patterns and magnitudes of the March 2011 temperature differences from climatology are similar to those seen in March 1997, but different from the Arctic response to both La Niña events and to the phase of the QBO. March zonal wind and February eddy heat flux differences are consistent with these conclusions. That is, the weak eddy heat flux in February and low temperatures in March 2011 are not related to either ENSO or the QBO. Note that, because the Niño 3.4 and QBO indices are slowly-varying, the above findings do not depend on the winter month and/or season used to represent the ENSO and QBO phases.

\subsection{Influence of North Pacific SSTs on the Arctic stratosphere in March}

As noted in Section 3.2, SSTs in the tropical Pacific and March polar cap temperatures are not correlated. However, SSTs in the North Pacific are strongly negatively correlated with March polar cap temperatures. For this study, a subarctic SST index is defined as the January/February mean SST anomaly from the 1979-2011 climatology, in the $40-50^{\circ} \mathrm{N}$, $160-200^{\circ} \mathrm{E}$ region. Variability in this region characterises the dominant mode of SST variability in the North Pacific in boreal winter i.e., the 'subarctic mode' identified by Nakamura et al. (1997). The subarctic mode is associated with SST variability at decadal timescales, caused by variability in the Kuroshio and Oyashio currents, and is not influenced by variability in the tropical Pacific (i.e., variability related to ENSO). Furthermore, the subarctic SST mode is not related to the Pacific Decadal Oscillation (PDO) (index updated from Mantua et al., 1997; Zhang et al., 1997). This section considers the influence of North Pacific SSTs on the Arctic troposphere and stratosphere in March.

The subarctic SST index was strongly positive in both 1997 and 2011 (Fig. 1f). The positive phase of the subarctic SST mode tends to weaken the Aleutian low and thus the Pacific-North American (PNA) and Western Pacific (WP) teleconnection patterns. Both the PNA and WP indices were strongly negative in December and January during the 19961997 and 2010-2011 winters. Equally, winters when the subarctic SST index was most negative (e.g., 1987-1988) include months with strongly positive values of the PNA and WP indices. Previous work has linked weakening of the PNA and WP teleconnection patterns with stratospheric variability: Orsolini et al. (2009) and Garfinkel et al. (2010) found that variability in the Aleutian low modulates the strength of the Arctic vortex in mid- and late winter. Nishii et al. (2010) found that extreme positive WP events in early winter can lead to persistent stratospheric cold periods and high PSC volumes in later months.

On average, the positive phase of the subarctic SST mode is associated with a relative cooling of the Arctic stratosphere. The subarctic SST index and March polar cap temperature at $50 \mathrm{hPa}$ are anti-correlated (with a correlation coefficient of -0.45 ; Fig. 2, right). Figure $3 e$ shows the difference between March temperatures in years when the subarctic SST index is strongly positive as compared with years when the index is strongly negative: The Arctic stratosphere is relatively colder (by approximately $6 \mathrm{~K}$ at $50 \mathrm{hPa}$ ), while below $500 \mathrm{hPa}$ the Arctic is approximately $2 \mathrm{~K}$ warmer. The structure and magnitude of these temperature differences are broadly consistent with the March temperature anomalies 

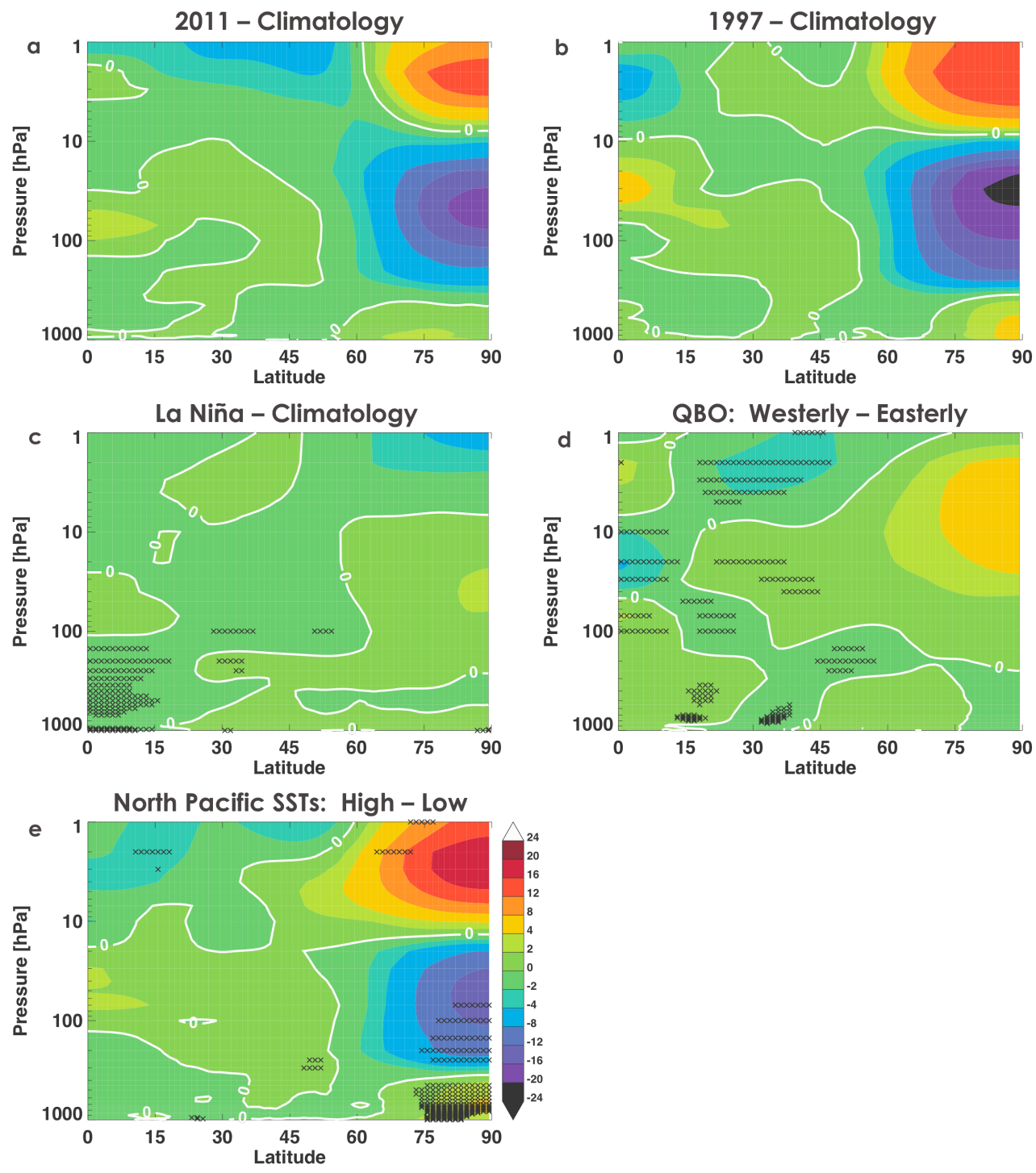

Fig. 3. March temperature differences [K]: (a) 2011 from the 1979-2011 climatological mean (i.e., blue contours indicate regions where March 2011 is cooler than the climatology); (b) 1997 from the climatological mean; (c) composite of La Niña events from the climatological mean; (d) QBO-westerly years - QBO-easterly years; (e) strongly positive subarctic SST years - strongly negative subarctic SST years (further discussed in the text). In (c), (d) and (e) black Xs denote differences significant at the $95 \%$ confidence level. Zero difference contours are shown in white.

observed in 1997 and 2011 (Fig. 3a and b), suggesting that North Pacific SST variability strongly contributed to variability in the Arctic stratosphere in March 1997 and 2011.

\section{Discussion}

Recent cooling of the Arctic lower stratosphere has been reported by e.g., Randel et al. (2009) and Kennedy et al. (2010). Rex et al. (2004 and 2006) noted a pattern of recent Arctic "cold winters getting colder". In the MERRA reanalysis in March, polar cap temperature at $50 \mathrm{hPa}$ decreased $0.17 \pm 0.14 \mathrm{~K} \mathrm{yr}^{-1}$ between 1979 and 2011. During this pe- riod, cooling of the Arctic lower stratosphere can be largely attributed to increased radiative forcing by greenhouse gases and to ozone depletion (Shine et al., 2003; Stolarski et al., 2010). However, this modest linear trend in March does not explain the anomalous conditions in 1997 and 2011, when the Arctic lower stratosphere was approximately $10 \mathrm{~K}$ below the climatological mean.

Similarly, the phase of the 11-yr solar cycle does not account for the anomalous conditions in March 2011. The solar cycle can be characterized by the solar flux at $2800 \mathrm{MHz}$ (ftp: //ftp.ngdc.noaa.gov/STP/SOLAR_DATA/SOLAR_RADIO/ FLUX/Penticton_Observed/monthly/MONTHLY.OBS); 
both 1997 and 2011 were within a few years of solar minima. Since the QBO was easterly in 1997 but westerly in 2011, the product of the solar cycle and QBO anomalies had the opposite sign in 1997 as compared with 2011. Though this quantity is well correlated with polar variability (Haigh and Roscoe, 2006), it does not explain the anomalously strong vortex events in both 1997 and 2011.

ENSO and the QBO do not explain the unusual dynamical conditions in March 2011. While La Niña conditions tend to strengthen the Arctic vortex in mid-winter, the La Niña signal weakens and begins to reverse by March. In Goddard Earth Observing System Chemistry-Climate Model, Version 2 (GEOS V2 CCM) simulations (model formulation as described by Hurwitz et al., 2011; La Niña simulation as described by Garfinkel et al., 2011), the Arctic lower stratosphere is cooler in March under La Niña and QBOwesterly conditions, as compared with ENSO neutral and QBO-easterly; however; the magnitude of this cooling is an order of magnitude less than observed in March 2011. Furthermore, the structure and magnitude of dynamical anomalies in the Arctic stratosphere were similar in March 1997 and March 2011, despite different phases of the QBO.

Positive SST anomalies in the North Pacific likely contributed to the anomalous conditions in March 2011. Positive SST anomalies in the $40-50^{\circ} \mathrm{N}, 160-200^{\circ} \mathrm{E}$ region in January and February, such as those observed in 1997 and 2011, are anti-correlated with polar lower stratospheric temperature anomalies in March. Positive SSTs in this region tend to weaken the Aleutian low, leading to a reduced eddy heat flux entering the stratosphere (Garfinkel et al., 2010). However, the relationship between North Pacific SSTs and stratospheric variability is non-linear: While multiple linear regressions to either February eddy heat flux or March polar cap temperature show that the subarctic SST mode is, statistically, the dominant cause of dynamical variability, these linear regressions do not capture the extreme values seen in e.g., 1997 and 2011.

\section{Conclusions}

Unusual dynamical conditions were observed in the Arctic stratosphere in March 2011. Tropospheric planetary wave driving was unusually weak, consistent with a strong, stable Arctic vortex in late winter and a relatively late vortex breakup. From a zonal mean perspective, the dynamical conditions observed in 2011 were not unprecedented: February eddy heat flux was weaker and March polar cap temperature was lower in 1997 than in 2011.

While ENSO, the QBO and greenhouse gas-related climate change do not explain the unusual polar stratospheric conditions in March 2011, analysis of the subarctic SST mode suggests that unusually warm SSTs in the North Pacific may have contributed to the remarkable cooling of the Arctic lower stratosphere in both 1997 and 2011. A planned modelling study will, by comparing time-slice simulations of the positive and negative extremes of the subarctic SST mode, isolate the impact of North Pacific SSTs on dynamics and ozone in the Arctic winter and spring.

Acknowledgements. The authors thank Eric Nash for providing vortex breakup dates, the chemistry-climate modelling group at NASA GSFC and two anonymous referees for their helpful feedback, and NASA's ACMAP program for funding.

Edited by: W. Lahoz

\section{References}

Bosilovich, M.: NASAS modern era retrospective-analysis for research and applications: integrating earth observations, Earthzine, available online at: http://www.earthzine.org/2008/09/26/ nasas-modern-era-retrospective-analysis/, 26 September 2008.

Finger, F. G., Gelman, M. E., Wild, J. D., Chanin, M. L., Hauchecorne, A., and Miller, A. J.: Evaluation of NMC upper stratospheric temperature analyses using rocketsonde and lidar data, B. Am. Meteorol. Soc., 74, 789-799, 1993.

Garfinkel, C. I., Butler, A. H., Waugh, D. W., and Hurwitz, M. M.: Why might SSWs occur with equal frequency in El Niño and La Niña winters? in preparation, 2011.

Garfinkel, C. I. and Hartmann, D. L.: Different ENSO teleconnections and their effects on the stratospheric polar vortex, J. Geophys. Res., 113, D18114, doi:10.1029/2008JD009920, 2008.

Garfinkel, C. I., Hartmann, D. L., and Sassi, F.: Tropospheric precursors of anomalous Northern Hemisphere stratospheric polar vortices, J. Climate, 23, 3282-3299, doi:10.1175/2010JCLI3010.1, 2010.

Gelman, M. E., Miller, A. J., Johnson, K. W., and Nagatani, R. M.: Detection of long-term trends in global stratospheric temperature from NMC analyses derived from NOAA satellite data, Adv. Space Res., 6, 17-26, 1986.

Haigh, J. D. and Roscoe, H. K.: Solar influences on polar modes of variability, Meteologische Zeitschrift, 15, 371-378, 2006.

Holton, J. R. and Tan, H.-C.: The Influence of the equatorial quasibiennial oscillation on the global circulation at $50 \mathrm{mb}$, J. Geophys. Res., 37, 2200-2208, 1980.

Hurwitz, M. M., Song, I.-S., Oman, L. D., Newman, P. A., Molod, A. M., Frith, S. M., and Nielsen, J. E.: Response of the Antarctic stratosphere to warm pool El Niño events in the GEOS CCM, Atm. Phys. Chem., 11, 9659-9669, doi:10.5194/acp-11-96592011, 2011.

Kalnay, E., Kanamitsu, M., Kistler, R., Collins, W., Deaven, D., Gandin, L., Iredell, M., Saha, S., White, G., Woollen, J., Zhu, Y., Chelliah, M., Ebisuzaki, W., Higgins, W., Janowiak, J., Mo, K. C., Ropelewski, C., Wang, J., Leetmaa, A., Reynolds, R., Jenne, R., and Joseph, D.: The NCEP/NCAR 40-year reanalysis project, B. Am. Meteorol. Soc., 77, 437-471, 1996.

Kennedy, J., and Parker, D.: Global and regional climate in 2009, Weather, 65, 244-250, 2010.

Kanamitsu, M., Ekisuzaki, W., Woollen, J., Yang, S.-K., Hnilo, J. J., Fiorino, M., and Potter, G. L.: NCEP-DOE AMIP-II reanalysis (R-2), B. Amer. Meteorol. Soc., 83, 1631-1643, 2002. 
Lu, H., Baldwin, M. P., Gray, L. J., and Jarvis, M. J.: Decadalscale changes in the effect of the QBO on the northern stratospheric polar vortex, J. Geophys. Res., 113, D10114, doi:10.1029/2007JD009647, 2008.

Manney, G. L., Santee, M. L., Rex, M., Livesey, N. J., Pitts, M. C., Veefkind, P., Nash, E. R., Wohltmann, I., Lehmann, R., Froidevaux, L., Poole, L. R., Schoeberl, M. R., Haffner, D. P., Davies, J., Dorokhov, V., Gernandt, H., Johnson, B., Kivi, R., Kyro, E., Larsen, N., Levelt, P. F., Makshtas, A., McElroy, C. T., Nakajima, H., Parrondo, M. C., Tarasick, D. W., von der Gathen, P., Walker, K. A., and Zinoviev, N. S.: Unprecedented Arctic ozone loss in 2011, Nature, doi:10.1038/nature10556, 2011.

Mantua, N. J., Hare, S. R., Zhang, Y., Wallace, J. M., and Francis, R. C.: A Pacific interdecadal climate oscillation with impacts on salmon production, B. Am. Meteorol. Soc., 78, 1069-1079, 1997.

Nagatani, R. M., Miller, A. J., Johnson, K. W., and Gelman, M. E.: An eight-year climatology of meteorological and SBUV ozone data, NOAA Tech. Rep. NWS 40, 125 pp., Natl. Weather Serv., Washington, DC, 1988.

Nakamura, H., Lin, G., and Yamagata, T.: Decadal climate variability in the North Pacific during the recent decades, B. Am. Meteorol. Soc., 78, 2215-2225, 1997.

Nash, E. R., Newman, P. A., Rosenfield, J. E., and Schoeberl, M. R.: An objective determination of the polar vortex using Ertel's potential vorticity, J. Geophys. Res., 101, 9471-9478, 1996.

Newman, P. A., Nash, E. R., and Rosenfield, J. E.: What controls the temperature of the Arctic stratosphere during the spring?, J. Geophys. Res., 106, 19999-20010, 2001.

Nishii, K., Nakamura, H., and Orsolini, Y. J.: Cooling of the wintertime Arctic stratosphere induced by the Western Pacific teleconnection pattern, Geophys. Res. Lett., 37, L13805, doi:10.1029/2010GL043551, 2010.

Orsolini, Y. J., Karpechko, A., and Nikulin, G.: Variability of the northern hemisphere polar stratospheric cloud potential: the role of North Pacific disturbances, Q. J. Roy. Meteorol. Soc., 135, 1020-1029, doi:10.1002/qj.409, 2009.

Randel, W. J., Shine, K. P., Austin, J., Barnett, J., Claud, C., Gillett, N. P., Keckhut, P., Langematz, U., Lin, R., Long, C., Mears, C., Miller, A., Nash, J., Seidel, D. J., Thompson, D. W. J., Wu, F., and Yoden, S.: An update of observed stratospheric temperature trends, J. Geophys. Res., 114, D02107, doi:10.1029/2008JD010421, 2009.

Rayner, N. A., Parker, D. E., Horton, E. B., Folland, C. K., Alexander, L. V., Rowell, D. P., Kent, E. C., and Kaplan, A.: Global analyses of sea surface temperature, sea ice, and night marine air temperature since the late nineteenth century, J. Geophys. Res., 108, 4407, doi:10.1029/2002JD002670, 2003.

Rex, M., Salawitch, R. J., von der Gathen, P., Harris, N. R. P., Chipperfield, M. P., and Naujokat, B.: Arctic ozone loss and climate change, Geophys. Res. Lett., 31, L04116, doi:10.1029/2003GL018844, 2004.
Rex, M., Salawitch, R. J., Deckelmann, H., von der Gathen, P., Harris, N. R. P., Chipperfield, M. P., Naujokat, B., Reimer, E., Allaart, M., Andersen, S. B., Bevilacqua, R., Braathen, G. O., Claude, H., Davies, J., De Backer, H., Dier, H., Dorokhov, Fast, H., Gerding, M., Godin-Beekmann, S., Hoppel, K., Johnson, B., Kyro, E., Litynska, Z., Moore, D., Nakane, H., Parrondo, M. C., Risley, A. D., Skrivankova, P., Stubi, R., Viatte, P., Yushkov, V., and Zerefos, C.: Arctic winter 2005: implications for stratospheric ozone loss and climate change, Geophys. Res. Lett., 33, L23808, doi:10.1029/2006GL026731, 2006.

Rienecker, M. M., Suarez, M. J., Gelaro, R., Todling, R., Bacmeister, J., Liu, E., Bosilovich, M. G., Schubert, S. D., Takacs, L., Kim, G.-K., Bloom, S., Chen, J., Collins, D., Conaty, A., da Silva, A., Gu, W., Joiner, J., Koster, R. D., Lucchesi, R., Molod, A. M., Owens, T., Pawson, S., Pegion, P., Redder, C. R., Reichle, R., Robertson, F. R., Ruddick, A. G., Sienkiewicz, M., and Woollen, J.: MERRA - NASA's Modern-Era Retrospective, Anal. Res. Appl., J. Climate, 24, 3624-3648, doi:10.1175/JCLID-11-00015.1, 2011.

Shine, K. P., Bourqui, M. S., Forster, P. M. D., Hare, S. H. E., Langematz, U., Braesicke, P., Grewe, V., Ponater, M., Schnadt, C., Smiths, C. A., Haigh, J. D., Austin, J., Butchart, N., Shindell, D. T., Randel, W. J., Nagashima, T., Portmann, R. W., Solomon, S., Seidel, D. J., Lanzante, J., Klein, S., Ramaswamy, V., and Schwarzkopf, M. D.: A comparison of model-simulated trends in stratospheric temperatures, Q. J. Roy. Meteorol. Soc., 129, 590, 1565-1588, 2003

Stolarski, R. S., Douglass, A. R., Newman, P. A., Pawson, S., and Schoeberl, M. R.: Relative contribution of greenhouse gases and ozone-depleting substances to temperature trends in the stratosphere: a chemistry-climate model study, J. Climate, 23, 26-42, 2010.

Stolarski, R. S. and Frith, S. M.: Search for evidence of trend slowdown in the long-term TOMS/SBUV total ozone data record: the importance of instrument drift uncertainty, Atmos. Chem. Phys., 6, 4057-4065, doi:10.5194/acp-6-4057-2006, 2006.

Trenberth, K. E.: The definition of El Niño, B. Am. Meteorol. Soc., 78, 2771-2777, 1997.

Wallace, J. M. and Gutzler, D. S.: Teleconnections in the geopotential height field during the Northern Hemisphere winter, Mon. Weather Rev., 109, 784-812, doi:10.1175/15200493(1981)109<0784:TITGHF>2.0.CO;2, 1981.

World Meteorological Organization (WMO): Scientific assessment of ozone depletion: 2010, Global Ozone Research and Monitoring Project, Rep. No. 52, 516 pp., Geneva, Switzerland, 2011.

Woollings, T., Charlton-Perez, A., Ineson, S., Marshall, A. G., and Masato, G.: Associations between stratospheric variability and tropospheric blocking, J. Geophys. Res., 115, D06108, doi:10.1029/2009JD012742, 2010.

Zhang, Y., Wallace, J. M., and Battisti, D. S.: ENSO-like interdecadal variability: 1900-93, J. Climate, 10, 1004-1020, 1997. 